Int. J. Agril. Res. Innov. Tech. 10(2): 15-20, December 2020 Available online at https://ijarit.webs.com DOI: https://doi.org/10.3329/ijarit.v10i2.51571 https://www.banglajol.info/index.php/IJARIT

\title{
Application of probiotics and prebiotics for promoting growth of Tiger shrimp (Penaeus monodon): an approach to eco-friendly shrimp aquaculture
}

\author{
J. Bir ${ }^{1 *}$, M.R. Golder ${ }^{1}$, S.K. Biswas ${ }^{1,2}$, S.S. Islam ${ }^{1,3}$, R. Kumar ${ }^{4}$ and K.A. Huq ${ }^{1}$ \\ Received 11 May 2020, Revised 9 September 2020, Accepted 24 December 2020, Published online 31 December 2020
}

\begin{abstract}
A B S T R A C T
The current study has been conducted to evaluate the growth performance of shrimp (Penaeus monodon) by applying eco-friendly culture mechanism like prebiotics and probiotics. The experiment was carried out for 95 days in different shrimp farms at coastal district of Bagerhat, Bangladesh. Three different treatments viz., probiotic treated as T1, prebiotics treated as T2 and both probiotics and prebiotics as T3 with a control group were designed to conduct the experiment. The size of the experimental ponds was five acre and the stocking density was $4 / \mathrm{m}^{2}$ in each treatment. CP NASA shrimp feed (32\% protein) was given thrice in a day during the study period. After 95 days of culture period, the maximum weight gain was observed at $\mathrm{T}_{3}(33.78 \pm 0.18 \mathrm{~g})$ whereas the minimum weight gain was observed at control group (25.69 $\pm 0.10 \mathrm{~g})$. The survival rate was the highest in $\mathrm{T} 3(89.01 \%)$ followed by $\mathrm{T} 2(75.51 \%)$ and $\mathrm{T} 1(53.44 \%)$ and the lowest rate was observed in control group (50.88\%). Overall production was higher in T3 $\left(833.78 \mathrm{~kg} \mathrm{ha}^{-1}\right)$ compared to T2 (553.40 kg $\left.\mathrm{ha}^{-1}\right)$, T1 (447.84 $\mathrm{kg} \mathrm{ha}^{-1}$ ) and Control group (310.57 $\left.\mathrm{kg} \mathrm{ha}^{-1}\right)$. $\mathrm{pH}$ value was found to maximum in $\mathrm{T}_{3}(7.71 \pm 0.08)$ and it was minimum in $\mathrm{T} 1(7.41 \pm 0.10)$. In addition, the maximum TAN value was found to be $2.22 \pm 0.19 \mathrm{mg} \mathrm{L}^{-1}$ in $\mathrm{C}$ pond and it was minimum in $\mathrm{T}_{3}$ $\left(0.32 \pm 0.06 \mathrm{mg} \mathrm{L}^{-1}\right)$. Therefore, it could be concluded that combine application of probiotics and prebiotics might be the reliable media to enhance production of shrimp by maintaining eco-friendly environment in aquaculture.
\end{abstract}

Keywords: Probiotics, Prebiotics, Eco-friendly, Growth, Shrimp.

\footnotetext{
${ }^{1}$ Fisheries and Marine Resources Technology Discipline, Khulna University, Bangladesh.

${ }^{2}$ Aquaculture Extension Manager, Community Development Centre (CODEC), SAFETI Project, Bangladesh.

${ }^{3}$ Institute for Marine and Antarctic Studies (IMAS), University of Tasmania, Australia.

${ }^{4}$ Senior Upazila Fisheries Officer, Department of Fisheries (DoF), Ministry of Fisheries and Livestock, Bangladesh.

*Corresponding author's email: joy@fmrt.ku.ac.bd (J. Bir)
}

Cite this article as: Bir, J., Golder, M.R., Biswas, S.K., Islam, S.S., Kumar, R. and Huq, K.A. 2020. Application of probiotics and prebiotics for promoting growth of tiger shrimp (Penaeus monodon): an approach to ecofriendly shrimp aquaculture. Int. J. Agril. Res. Innov. Tech. 10(2): 15-20. https://doi.org/10.3329/ijarit.v10i2.51571

\section{Introduction}

The shrimp sector in Bangladesh is very unique compared to other fisheries and supported large coastal fishing industrial development (Howlader et al., 2020). More than $95 \%$ of shrimp and prawn in Bangladesh are produced in extensive polyculture ponds that were formerly used as rice ponds and are locally referred to as 'Ghers'. The culture of Penaeus monodon (black tiger shrimp), locally referred to as 'Bagda', is mostly combined with the culture of other shrimp species that are trapped in the gher when water is taken in (DoF, 2017; Ghosh, 2018; Howlader et al., 2020). The culture of Macrobrachium rosenbergii (Giant freshwater prawn) takes place in smaller ponds and is mostly combined with the culture of rice and/or freshwater fishes (Ghosh et al., 2016). $M$. rosenbergii is mostly (over 95\%) produced by small-scale farmers, who harvest only a few $\mathrm{kg}$ of large shrimp per day. Shrimp exports total over 40,000 tonnes of $P$. monodon, $M$. rosenbergii and some smaller volumes of other species in 2016 and 2017 (Azad et al., 2019). Over 80\% was exported to the EU market in 2017, especially to the Netherlands, Germany and Belgium. There are more than 70 factories approved by the Department of Fisheries (DoF) in Bangladesh, but only 40-50 are operational (FAO, 2013; Hossain et al., 2013).

Shrimp and prawn together represent the second largest exportable items contributing to foreign 
exchange earnings of Bangladesh (Ghosh et al., 2016; Azad et al., 2019). Shrimp farming has significant impact on environment and economy. Although the country has a great history of shrimp/prawn farming, the productivity of shrimp is very low compare to the other shrimp producing countries of the world (Rahman and Rashid, 2013). One of the major causes of poor productivity is the extensive or traditional method of farming (90 percent of total farms), whereas developed countries brought their farms under intensive or semi-intensive methods of farming (Azad et al., 2019). Bangladesh has great potentiality to increase productivity of shrimp and prawn by introducing intensive and semiintensive methods of farming (Rahman and Rashid, 2013).

Although shrimp industries having a great contribution in the economy of Bangladesh as well many developing countries (Alam and Ahammad, 2017). But, the industries have facing lot of challenge in recent decays. As a result, production and quality of shrimp commodities are also declining gradually (Ghosh, 2018). Now a day the current aquaculture moved to ecofriendly culture system (Shingare et al., 2020). Different types of environment friendly culture methods have been developed. Probiotics and prebiotics are one of the most popular ecofriendly culture systems around the world (Kumar et al., 2016; Shefat, 2018; Shingare et al., 2020). Probiotic are heterotrophic beneficial bacteria that remove deleterious nitrogenous compound from the aquatic system (Fernandes and Kerkar, 2019). The principal mode of action of probiotic bacteria is through competitive exclusion mechanisms in which pathogens are replaced or excluded through the development of a beneficial microbial population on the intestinal surface which leads to a reduction in disease, better health and thus better growth of the host (Jha, 2014; Azad et al., 2019).

Thus, probiotics act as the alternatives of antibiotics and chemicals reducing diseases through maintaining pollution free environment (Kumar et al., 2016; Fernandes and Kerkar, 2019). On the other hand, prebiotics acts as free carbon source that helps heterotrophic bacteria to digest ammonia. It also ensures enough oxygen, stabilize the $\mathrm{pH}$ and balance the density of algaebacteria ratio.

Considering that aspect, current study was conducted to focus the effect of probiotics and prebiotics on shrimp production in the southern coastal region of Bangladesh. The current research focused on assessing growth performance of shrimp through eco-friendly culture practices with the application of probiotics and prebiotics.

\section{Methodology}

\section{Experimental site and size}

Field experiment was carried out directly on the farmers' commercial shrimp farms. A total 12 commercial farms were selected. The average area of the pond was with $1.5 \mathrm{~m}$ depth and the farmers mostly practices conventional shrimp farming without the application of probiotics and prebiotics.

\section{Experimental species}

The experiment only focused on Shrimp monoculture techniques. Specific Pathogen Free (SPF) shrimp larvae Penaeus monodon was cultured and observed their growth performance by applying different probiotics and prebiotics. Shrimp post larvae (PL) of 15 days old was collected from a commercial hatchery located at Cox's Bazar district of Bangladesh.

\section{Description of probiotics and its application}

Three different commercial probiotics were selected considering on their function, compositions, mood of application such as soil, water and gut probiotics and obviously on their economics aspect (Table 1).

Table 1. Information about applied probiotics with its composition and mode of application.

\begin{tabular}{|c|c|c|c|c|}
\hline $\begin{array}{l}\text { Type of } \\
\text { probiotics }\end{array}$ & $\begin{array}{l}\text { Microbial } \\
\text { composition }\end{array}$ & $\begin{array}{l}\text { Manufacturing } \\
\text { company }\end{array}$ & $\begin{array}{l}\text { Marketing } \\
\text { agency }\end{array}$ & Mode of application \\
\hline $\begin{array}{c}\text { Soil } \\
\text { probiotics }\end{array}$ & $\begin{array}{l}\text { Rhodobacter sp. } \\
\text { and Rhodococcus }\end{array}$ & $\begin{array}{c}\text { Kyushu Medical Co. } \\
\text { Ltd, Japan }\end{array}$ & Fish-Tech & $\begin{array}{l}7 \text { days prior of PL stocking at dosage } \\
150 \mathrm{ml} / \text { decimal and continue with } \\
10 \text { days interval during the culture } \\
\text { period at dosage } 100 \mathrm{ml} / \text { decimal. }\end{array}$ \\
\hline $\begin{array}{l}\text { Water } \\
\text { probiotics }\end{array}$ & $\begin{array}{l}\text { Bacillus subtilis } \\
\text { and Bacillus } \\
\text { licheniformis }\end{array}$ & $\begin{array}{l}\text { INVE (Thailand) } \\
\text { Ltd }\end{array}$ & $\begin{array}{l}\text { INVE } \\
\text { Aquaculture }\end{array}$ & $\begin{array}{l}7 \text { days prior of PL stocking at dosage } \\
\text { o.5 g/decimal and continue with } 10 \\
\text { days interval during the culture } \\
\text { period at dosage } 1.0 \mathrm{~g} / \text { decimal. }\end{array}$ \\
\hline $\begin{array}{l}\text { Gut } \\
\text { probiotics }\end{array}$ & $\begin{array}{l}\text { B. mensentericus, } \\
\text { Bacillus subtilis } \\
\text { and Licheniformis, } \\
\text { Nitrobacter sp. }\end{array}$ & $\begin{array}{l}\text { Murdoch } \\
\text { University, } \\
\text { Australia \& Inje } \\
\text { University }\end{array}$ & $\begin{array}{l}\text { UniBioCare } \\
\text { (BD) } \\
\text { Corporation }\end{array}$ & $\begin{array}{l}\text { Mix with daily feed for shrimp at } \\
\text { dosage } 1-2 \mathrm{~g} / \mathrm{kg} \text { feed. }\end{array}$ \\
\hline
\end{tabular}




\section{Preparation of prebiotics}

Prebiotics was prepared by using locally available ingredients such as rice bran/auto polish, molasses, yeast powder these are the major component that is very available near the hand (Table 2). In this process rice bran, molasses and yeast powder is taken in required amount and mixed in water. The amount of water should be 10 times more than the total mixture weight.
Then the mixture is kept in a plastic drum or other jar that must have lid to cover and it needs at least 24-72 hours to ferment. After the fermentation the solution must be filtered with small meshed cloths or net and collect only the water that should be sprinkled all over the farm water. Each time of application, newly prepared prebiotics should be applied.

Table 2. Ingredients used to prepare prebiotics and their specification with functions.

\begin{tabular}{|c|c|c|}
\hline Ingredients \& support materials & Amount/Acre & $\begin{array}{l}\text { Specification } \\
\end{array}$ \\
\hline Rice polish (Auto Polish) & $4 \mathrm{~kg}$ & Source of carbohydrates. \\
\hline Molasses & $4 \mathrm{~kg}$ & $\begin{array}{l}\text { Fructooligosaccharides. } \\
\text { Help to increase microbial and plankton number. }\end{array}$ \\
\hline Yeast Powder & $100 \mathrm{~g}$ & $\begin{array}{l}\text { Single cell micro-organism of the Saccharomyces } \\
\text { cerevisae used for fermentation and important } \\
\text { source of carbon-di-oxide. }\end{array}$ \\
\hline Water & $\begin{array}{l}10 \text { times than } \\
\text { the mixture }\end{array}$ & $\begin{array}{l}\text { Help to mix all ingredients properly with pond } \\
\text { environment. }\end{array}$ \\
\hline
\end{tabular}

\section{Experiment set up}

The experiment was conducted with four treatments including a control. The treatment group were expressed as $T_{1}$ (with only prebiotics, $\mathrm{T}_{2}$ (using only probiotics), $\mathrm{T}_{3}$ (using both prebiotics and probiotics) and $\mathrm{C}$ as control pond using none of these. All other management like stocking density $\left(4 / \mathrm{m}^{2}\right)$ feed, feeding methods, liming etc. were similar throughout the experimental period.

\section{Feeding management}

Commercial supplementary feed formulated by CP India Ltd for shrimp was used containing fish meal, shrimp head meal, cod liver-oil, squid meal, broken rice, soybean meal, wheat flour, cholesterol, phospholipids, vitamins and minerals (Leaflet of CP Feed). Before feeding, the feed was analysed to determine the proximate composition according to the standard procedures given by Association of Official Analytical Chemists (AOAC, 1980). The average percentage of protein, fat and moisture was 31,7 and $12 \%$, respectively in the feed. Feed was given according to the body weight and the age of shrimp. At first month, feed was given at $10 \%$ of total shrimp body weight, and then up to five months feed was given at $5 \%$ of body weight, and last two months the feed was given at $2 \%$ of the total body weight of shrimp (the average weight of shrimp was multiplied by the total number of shrimp to calculate total weight) (Table 3). Feed was spread over the pond surface three times in a day at $30 \%(6.00 \mathrm{am})$, $30 \%(12.00 \mathrm{pm})$ and $40 \%(6.00 \mathrm{pm})$ of the total feed allocated for the shrimp.

Table o. Feed Chart followed in treatment (CPF-2017, India) for 1000 individual.

\begin{tabular}{|c|c|c|c|c|c|c|}
\hline $\begin{array}{c}\text { Age } \\
\text { (Days) }\end{array}$ & $\begin{array}{c}\text { Average body } \\
\text { weight }(\mathrm{g})\end{array}$ & $\begin{array}{c}\text { Weight of } \\
\text { 1000 shrimp } \\
(\mathrm{kg})\end{array}$ & $\begin{array}{c}\text { Feeding ratio } \\
\text { (\% body } \\
\text { weight) }\end{array}$ & $\begin{array}{c}\text { Daily } \\
\text { feed (g) }\end{array}$ & $\begin{array}{c}\text { Total feed } \\
(\mathrm{kg}) / \text { week }\end{array}$ & $\begin{array}{c}\text { Feeding } \\
\text { frequency/day }\end{array}$ \\
\hline $1-7$ & 0.8 & 0.8 & 10.0 & 0.080 & 0.560 & 3 \\
\hline $8-14$ & 1.5 & 1.5 & 9.0 & 0.135 & 0.945 & 3 \\
\hline $15-21$ & 4.0 & 4.0 & 5.5 & 0.220 & 1.540 & 3 \\
\hline $22-28$ & 6.0 & 6.0 & 5.0 & 0.300 & 2.100 & 3 \\
\hline $29-35$ & 8.5 & 8.5 & 4.4 & 0.374 & 2.618 & 3 \\
\hline $36-42$ & 10.0 & 10.0 & 4.1 & 0.410 & 2.870 & 3 \\
\hline $43-49$ & 12.0 & 12.0 & 3.8 & 0.456 & 3.192 & 3 \\
\hline $50-56$ & 15.0 & 15.0 & 3.4 & 0.510 & 3.570 & 3 \\
\hline $57-63$ & 18.0 & 18.0 & 3.0 & 0.540 & 3.780 & 3 \\
\hline $64-70$ & 21.5 & 21.5 & 2.6 & 0.559 & 3.913 & 3 \\
\hline $71-77$ & 24.0 & 24.0 & 2.4 & 0.576 & 4.032 & 3 \\
\hline $78-84$ & 27.0 & 27.0 & 2.3 & 0.621 & 4.347 & 3 \\
\hline $85-91$ & 30.0 & 30.0 & 2.2 & 0.660 & 4.620 & 3 \\
\hline
\end{tabular}




\section{Sampling and growth measurement}

The culture was done for 95 days. Sampling was done regularly at every week. The water salinity of the pond was measured by using a hand Refractometer (Erma-Japan). The pH, alkalinity, total ammonia nitrogen (TAN) of the pond water was recorded by using $\mathrm{pH}$ test kit, alkalinity kit and ammonia test kit, respectively (Advance Pharma, Thailand). Water temperature was measured by using a standard centigrade thermometer.

\section{Statistical analysis}

All data were analysed statistically using SPSS version 16.0, Chicago, SPSS lnc. Normality test done by Shapiro-Wilk to check for normal distribution and homogeneity of variance. Only percent data had to be arcsine transformed before analysis; however, non-transformed data are presented in tables. Least significance difference (LSD) post hoc test on a one-way ANOVA was used to examine treatment effects on weight gain. All statistical analyses were considered at $5 \%$ $(p<0.05)$ level of significance.

\section{Results and Discussion}

\section{Growth, survival rate and production of P. monodon}

There were significant differences observed of the final mean body weight of shrimp among all treatment $(p<0.05)$ (Table 4$)$. After 95 days of culture period the highest mean body weight was found at $\mathrm{T} 3(33.78 \pm 0.18 \mathrm{~g})$ in which both probiotics and prebiotics were applied combined whereas lowest mean growth was in $\mathrm{T}_{4}$ $(25.69 \pm 0.10 \mathrm{~g})$ the control group (Table o). Similarly, Significant effect of prebiotics and probiotics also observed on survival rate of shrimp among all treatment $(p<0.05)$. The maximum survival rate was found at $\mathrm{T}_{3}(89.01 \%)$ whereas at control group the rate was almost half of the initial stocking. However, the overall production at $\mathrm{T} 33$ almost three time more than the control.

Table o. Body weight, \% survival rate and production (mean \pm standard error) of $P$. monodon treated with three different prebiotics and probiotics.

\begin{tabular}{|l|c|c|c|c|}
\hline & $\mathrm{C}$ & $\mathrm{T} 1$ & $\mathrm{~T} 2$ & $\mathrm{~T}$ \\
\hline Initial Weight $(\mathrm{g})$ & $0.74 \pm 0.01$ & $0.77 \pm 0.01$ & $0.81 \pm .01$ & $1.08 \pm 0.01$ \\
\hline Final Weight $(\mathrm{g})$ & $26.43 \pm 0.10$ & $27.81 \pm 0.10$ & $30.91 \pm 0.13$ & $34.85 \pm 0.18$ \\
\hline Weight gain $(\mathrm{g})$ & $25.69 \pm 0.10^{\mathrm{a}}$ & $27.04 \pm 0.11^{\mathrm{a}}$ & $30.10 \pm 0.13^{\mathrm{a}}$ & $33.78 \pm 0.18^{\mathrm{a}}$ \\
\hline Survival rate (\%) & $50.88 \pm 2.66$ & $53.44 \pm 0.95$ & $75.51 \pm 2.06$ & $89.01 \pm 1.90$ \\
\hline Production (kg/ha) & $310.56 \pm 81.20$ & $447.84 \pm 21.08$ & $553.40 \pm 50.81$ & $833.78 \pm 87.96$ \\
\hline
\end{tabular}

Different superscript letters (effect of prebiotics and probiotics) indicate significant difference among the treatments (One-way analysis of variance, $p<0.05$ ).

It is clearly observed from this experiment that the probiotics and prebiotics enhanced overall shrimp production. Although the combine application of probiotics and prebiotics dramatically help to get higher production. Similar scenario production performance by probiotic application also observed by Shingare et al., (2020) in Maharashtra India in shrimp polyculture, Ghosh et al., (2016) at Khulna region of Bangladesh in Prawn monoculture and Shefat, (2018) at shrimp farm in southern part Bangladesh.

Table 5. Analysis of Variance (ANOVA).

\section{Observation of probiotics and prebiotics interaction effect on individual growth variables}

The LSD post hoc test on a one-way ANOVA revealed that there was a statistically significant difference in body weight gain between the group of the control and all the treatments $(p=0.00)$ (Table 5).

\begin{tabular}{|c|c|c|c|c|c|c|}
\hline \multicolumn{7}{|c|}{ ANOVA } \\
\hline & & Sum of Squares & $\mathrm{df}$ & Mean Square & $\mathrm{F}$ & Sig. \\
\hline \multirow[t]{3}{*}{ IW } & Between Groups & 2.107 & 3 & 0.702 & 83.728 & 0.000 \\
\hline & Within Groups & 0.973 & 116 & 0.008 & & \\
\hline & Total & 3.080 & 119 & & & \\
\hline \multirow[t]{3}{*}{ FW } & Between Groups & 1257.900 & 3 & 419.300 & 748.789 & 0.000 \\
\hline & Within Groups & 64.957 & 116 & 0.560 & & \\
\hline & Total & 1322.857 & 119 & & & \\
\hline \multirow[t]{3}{*}{ WG } & Between Groups & 1163.272 & 3 & 387.757 & 677.350 & 0.000 \\
\hline & Within Groups & 66.406 & 116 & 0.572 & & \\
\hline & Total & 1229.678 & 119 & & & \\
\hline
\end{tabular}


Water quality parameter in experimental pond

$\mathrm{pH}$ value was found to be maximum in $\mathrm{T}_{3}$ (7.71 \pm 0.08$)$ and minimum in $\mathrm{T} 1 \quad(7.41 \pm 0.10)$ (Figure 1). In addition, the maximum TAN value was found to be $2.22 \pm 0.19 \mathrm{mg} \mathrm{L}^{-1}$ in $\mathrm{C}$ pond and minimum in $\mathrm{T}_{3}\left(0.32 \pm 0.06 \mathrm{mg} \mathrm{L}^{-1}\right)$ (Figure 1). From different earlier studies the normal $\mathrm{pH}$ of brackish water ranged between 7 to 9 for culturing shrimps and less than 7 or higher than 9 often found harmful to shrimp, even is detrimental to the health of the shrimps (Muthu, 1980). In the present study, the $\mathrm{pH}$ concentration

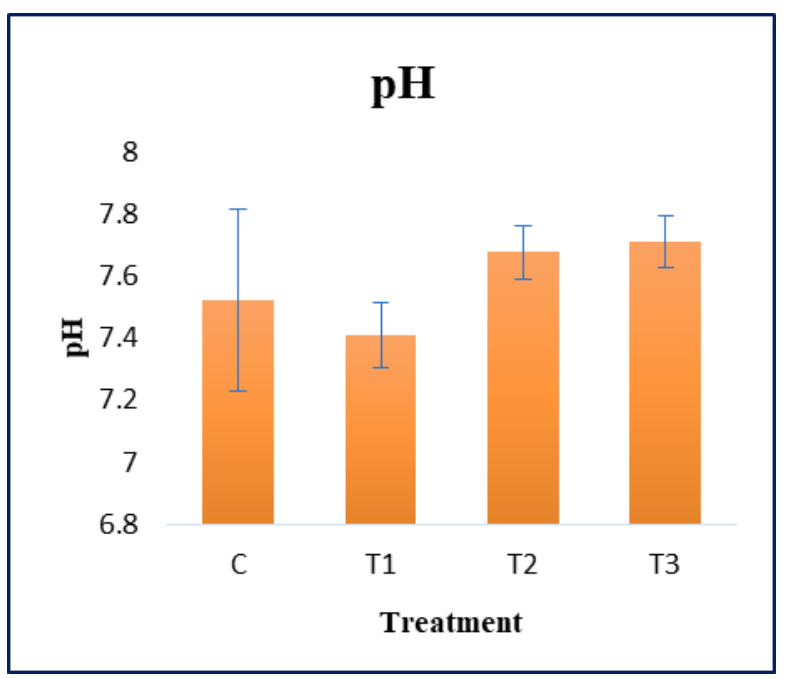

was ranged from $7.41 \pm 0.10$ to $7.71 \pm 0.08$, which were favorable for fish and shellfish culture (Ghosh et al., 2016). At farm level, Ammonia level should be less than $1 \mathrm{ppm}$ (Soundarapandian et al., 2010). In the present study, total ammonia nitrogen was $2.22 \pm 0.19$ and $0.32 \pm 0.06$ in control and prebiotics probiotics treated ponds, respectively. Thus, maintaining the ammonia level probiotic and prebiotics help in maintaining good water quality and thereby keeps the shrimp disease free (Hossain et al., 2013; Azad et al., 2019).

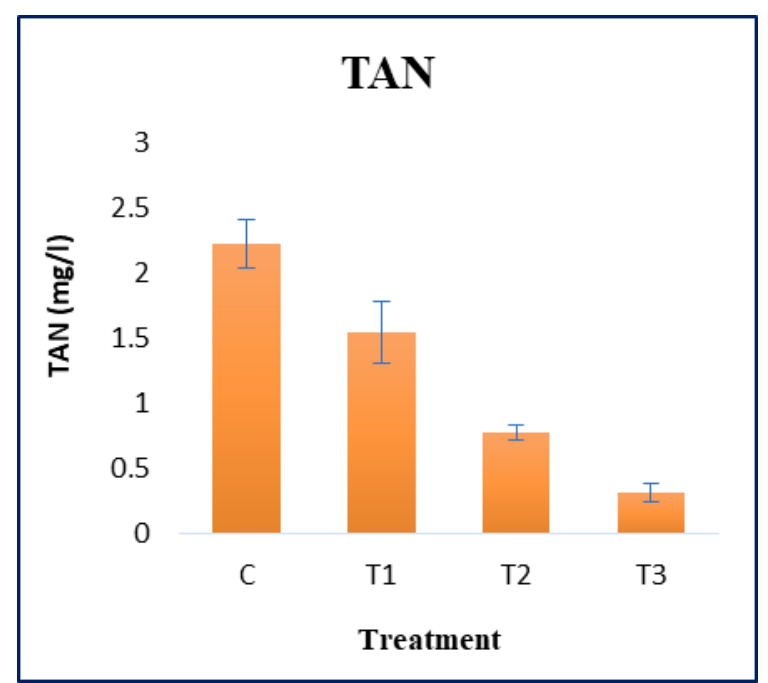

Figure 1. $\mathrm{pH}$ and TAN values in all ponds during the 3 months experimental period. The error bars indicate the standard error of the treatments.

Most often economic analysis is an important issue for this kind of study. Along with the production we also conducted cost benefits analysis and we found that our profit if almost double then the cost of experiments. Therefore, we can say applying both prebiotics and probiotics during the culture period, these components act as stress remover as well as decrease the pathogenic activity, that might increase the survival rate and enhance shrimp production along with the economically profitable eco-friendly aquaculture.

\section{Conclusion}

This study confirmed that highest shrimp growth and production was found in that treatment where both probiotics and prebiotics were used combined. As well probiotics increase survival rate of the species and produce healthy crops within three months. Along with this these ingredients plays a significant contribution to maintain suitable water quality especially main good TAN and $\mathrm{pH}$, which ensure ecofriendly pond environment and minimizing different kind of diseases. Therefore, it could be concluded that application of both prebiotics and probiotic in shrimp farm can be a profitable and ecofriendly culture techniques for coastal shrimp farmer.

\section{References}

Alam, S. and Ahammad, S.U. 2017. Shrimp aquaculture in Bangladesh: Domestic regulatory responses and compliance with MEAs. Marine Policy. 82: 122-133. https://doi.org/10.1016/j.marpol.2017.04.018

AOAC. 1980. Official methods of analysis (13th ed.). Association of Official Analytical Chemists. Washington D.C. pp. 376-384.

Azad, M.A.K., Islam, S.S., Sithi, I.N., Ghosh, A.K., Banu, G.R., Bir, J. and Huq, K.A. 2019. Effect of probiotics on immune competence of giant freshwater prawn Macrobrachium rosenbergii. Aqua. Res. 50(2): 644-657. https://doi.org/10.1111/are.13942

DoF. 2017. Yearbook of Fisheries Statistics of Bangladesh 2016-17. Fisheries Resources Survey System (FRSS), Department of Fisheries. Bangladesh: Director General, DoF, vol. 34, p. 129.

FAO. 2013. Characteristics, structure and resources of the sector. FAO Country Notes, 1380, Rome, Italy. pp. 1-16. 
Fernandes, S. and Kerkar, S. 2019. Bacterial probiotics over antibiotics: A boon to aquaculture. (eds. S.N. Meena and M.M. Naik) In: Advances in Biological Science Research. Academic Press, Elsevier. pp. 215232. https://doi.org/10.1016/B978-0-12-8174975.00014-8

Ghosh, A.K. 2018. Effect of feeding level on growth, body composition, fatty acid profile, and nutrient accumulation in shrimp (Litopenaeus vannamei). Aqua. Int. 26: 405-417. https://doi.org/10.1007/s10499-017$0225-\mathrm{Z}$

Ghosh, A.K., Bir, J., Azad, M.A.K., Hasanuzzaman, A.F.M., Islam, M.S. and Huq, K.A. 2016. Impact of commercial probiotics application on growth and production of giant fresh water prawn (Macrobrachium Rosenbergii De Man, 1879). Aqua. Rep. 4: 112-117. https://doi.org/10.1016/j.aqrep.2016.08.001

Hossain, M.I., Kamal, M.M., Mannan, M.A., Bhuyain, M.A.B. and Hossain, M.I. 2013. Effects of probiotics on growth and survival of shrimp (Penaeus monodon) in coastal pond at Khulna, Bangladesh. J. Sci. Res. 5(2): 363-370. https://doi.org/10.3329/jsr.v5i2.11815

Howlader, P., Ghosh, A.K., Islam, S.S., Bir, J. and Banu, G.R. 2020. Antiviral activity of Cynodon dactylon on white spot syndrome virus (WSSV)-infected shrimp: an attempt to mitigate risk in shrimp farming. Aqua. Int. 28: 1725-1738. https://doi.org/10.1007/s10499020-00553-W
Jha, A.K. 2014. Probiotics: an effective feed supplement in Shrimp culture. $J$. Bangladesh Acad. Sci. 38(2): 127-130. https://doi.org/10.3329/jbas.v38i2.21336

Kumar, V., Roy, S., Meena, D.K. and Sarkar, U.K. 2016. Application of probiotics in shrimp aquaculture: importance, mechanisms of action, and methods of administration. Rev. Fish. Sci. Aqua. 24(4): 342-368. https://doi.org/10.1080/23308249.2016.1193841

Muthu, M.S. 1980. Site selection and type of farms for coastal aquaculture of prawns. pp. 16-18. In: Proceedings of the Symposium on Shrimp Farming, Bombay, India.

Rahman, M.C. and Rashid, M.H.A. 2013. A case study on the present status and potentiality of shrimp farming in Bangladesh. AsiaPacific J. Rural Dev. 23(1): 97-110. https://doi.org/10.1177/1018529120130107

Shefat, S.H.T. 2018. Use of probiotics in shrimp aquaculture in Bangladesh, Acta Sci. Microbiol. 1(11): 20-27.

Shingare, P.E., Pagarkar, A.U., Chaudhari, K.J., Dhaker, H.S., Meshram, S.J., Sawant, N.H., Satam, S.B., Shingare, S.P., Sawant, B.T. and Sapkale, P.H. 2020. Eco-friendly and sustainable Asian seabass culture system: an alternate candidate species other than shrimp for brackish water aquaculture. $J$. Exp. Zool. 23 (Suppl. 1): 983-985.

Soundarapandian, P., Ramanan, V. and Dinakaran, G.K. 2010. Effect of probiotics on the growth and survival of Penaeus monodon (Fabricius). Current Res. J. Soc. Sci. 2(2): 51-57. 